\title{
Retrospective analysis of patients applying to a health board to determine disability rates
}

\author{
Sağlık kuruluna engellilik oranlarının belirlenmesi için başvuran hastaların \\ retrospektif analizi
}

\author{
๑İ̇smet Serhat Kahya ${ }^{1}$, ๑İlhan Uyaner ${ }^{1}$, ๑Abdullah Keskin ${ }^{1}$, \ustafa Engin Şahin ${ }^{2}$, \\ ๑İbrahim Serdar Kahya ${ }^{3}$, @Çiğdem Özdilekcan ${ }^{2}$, @Tarkan Özdemir ${ }^{2}$ \\ ${ }^{1}$ University of Health Sciences Dr. Abdurrahman Yurtaslan Oncology Education and Research Hospital, Department of Social Services, Ankara, Turkey \\ ${ }^{2}$ University of Health Sciences Atatürk Chest Diseases and Chest Surgery Education and Research Hospital, Department of Pulmonology, Ankara, Turkey \\ ${ }^{3}$ Altay Mechanical Heating Systems, Department of Project Management, Ankara, Turkey
}

Cite this article as/Bu makaleye atıf için: Kahya İS, Uyaner İ, Keskin A, et al. Retrospective analysis of patients applying to a health board to determine disability rates. J Med Palliat Care 2021; 2(4): 131-135.

\begin{abstract}
Introduction: Disabled is defined as a person who loses their physical, mental, spiritual, emotional, and social abilities to various degrees, and who therefore has difficulty in adapting to social life and meeting daily needs. Our aim is to analyze those patients who applied to our hospital's medical board due to disability and to contribute to the statistics available in this area.

Material and Method: Between 2015 and 2019, variables such as gender, age, disability rate, report duration, and additional diseases were analyzed among those patients who applied to Dr. Abdurrahman Yurtaslan Oncology Education and Research Hospital Health Board due to disability. Statistical Package for the Social Sciences (SPSS) version 21 (SPSS Inc., Chicago, IL, USA) was used for statistical analysis of the study data.

Results: Of the 2237 patients, $41.9 \%(n=938)$ were men and $58.1 \%(n=1299)$ were women. Patients' mean age, regardless of gender, was found to be $55.29 \pm 16.32$ years. Patients' average disability score was $66.4 \pm 21.29$; the three most common diseases were found to be cancer ( $\mathrm{n}=1339,28.19 \%$ ), endocrinological and metabolic diseases $(n=578,12.16 \%)$, and cardiovascular system diseases $(n=1056,22.23 \%)$, respectively. Patients with a disability rate of $40 \%$ or above comprised $90 \%(n=2013)$ of the total number of patients; $5.1 \%(n=115)$ of the patients were fully dependent. Among all those who received reports, the rate of patients who received continuous reports was $71.9 \%(n=1610)$. The proportion of patients under 65 years of age ( $n=1598,71.4 \%)$ was found to be higher than the proportion of patients above 65 years of age $(n=636,28.4 \%)$.

Conclusion: Hospital health boards play an important role in the detection and rating of disability. When we compared the data we obtained in our study with the literature, several differences could be found. It is thought that these differences may be related to hospital roles or differences in interpretation among the various health boards. For this reason, it is important to follow up whether the standards are applied as much as developing standards that will ensure unity in practice
\end{abstract}

Keywords: Balthazard, $40 \%$, disability report, cancer

\section{ÖZ}

Giriş: Engelli, doğuştan veya sonradan bedensel, zihinsel, ruhsal, duygusal ve sosyal yeteneklerini çeşitli derecelerde kaybeden bu nedenle toplumsal yaşama uyum sağlama ve günlük gereksinimlerini karşılamada zorluk çeken kişi olarak tanımlanmaktadır. Amacımız hastanemiz sağlık kuruluna engellilik nedeniyle başvuran hastaları analiz ederek bu alanda var olan istatistiklere katkıda bulunmaktır.

Gereç ve Yöntem: 2012-2019 yılları arasında Dr. Abdurrahman Yurtaslan Onkoloji Eğitim ve Araştırma Hastanesi Sağlık Kurulu’na engellilik nedeniyle başvuran hastalarda cinsiyet, yaş, engellilik oranı, rapor süresi, ek hastalıklar gibi değişkenler analiz edildi. İstatistiksel analiz için statistical package for the social sciences (SPSS) version 21 (SPSS Inc., Chicago, IL, USA) kullanıldı.

Bulgular: 2237 hastanın \%41,9’u (n=938) erkek, \%58,1’i (1299) kadınlardan oluşmaktaydı. Cinsiyet ayrımı olmaksızın bakılan yaş ortalaması 55,29 $\pm 16,32$, engellilik puanı ortalaması 66,4 $\pm 21,29$; en sık görülen ilk 3 hastalık 1. Kanser: n=1339 (\%28,19) 2. Endokrinolojik ve Metabolik Hastalıklar: n=578 (\%12,16) 3. Kardiyovasküler Sistem Hastalıkları: $n=1056(\% 22,23)$ olarak tespit edildi. Engellilik oranı \%40 ve üzeri olanlar, toplam hasta sayısının \%90’nı (n=2013) oluşturmaktaydı. Hastaların \%5,1’i (n=115) tam bağımlıdı. Tüm rapor alan hastalar arasında sürekli rapor alan hastaların oranı \%71,9 (n=1831) olarak tespit edildi. 65 yaş altı hastaların oranı $(\mathrm{n}=1598, \% 71,4) 65$ yaş üstü hastalardan $(\mathrm{n}=636, \% 28,4)$ daha fazla bulundu.

Sonuç: Engelliğin tespiti ve derecelendirilmesinde hastane sağlık kurulları önemli bir görevi yerine getirmektedir. Çalışmamızda elde ettiğimiz verileri literatür ile kıyasladığımızda farklılıkların olduğu görülmüştür. Bu durumun hastane rolleriyle ilişkisi olabileceği gibi sağlık kurulları arasındaki yorum farklılıklarından da kaynaklanabileceği düşünülmektedir. Bu nedenle uygulamada birlikteliği sağlayacak olan standartların geliştirilmesi kadar takibi de önem arz etmektedir.

Anahtar Kelimeler: Balthazard, \%40, engellilik oranı, kanser 


\section{INTRODUCTION}

Disability is part of being human. Almost everyone will be disturbed temporarily or permanently at some stage of their life, and will encounter increasing difficulties as they age (1). According to the definition made within the framework of the legislation in Turkey, a disabled person is someone "who loses his or her physical, mental, spiritual, emotional and social abilities at various degrees and therefore has difficulty in adapting to social life and meeting daily needs" (2). It is estimated that over one million people live with some form of disability in Turkey. Due to the aging population in Turkey and the increase in people with chronic health conditions, the number of people with disabilities is gradually increasing (3). The International Classification of Functioning, Disability, and Health (ICF) has provided definitions and classifications related to disability in order to create a common language (4). The rate of severe disability among the Turkish population is $2.9 \%$ across all age groups, while moderate and severe disability is $15.3 \%$. The severe disability rate among women was $0.7 \%$ for the 0-14 year age group, $2.8 \%$ for the 15-59 year age group, and $10.5 \%$ for the $60+$ year age group; comparatively, the severe disability rate among men was $0.7 \%$ for the $0-14$ year age group, $2.6 \%$ for the $15-59$ year age group, and $9.8 \%$ for the $60+$ year age group. The global rise in diabetes, cardiovascular diseases (heart disease and stroke), mental disorders, cancer, and respiratory diseases will have a profound effect on disability. These diseases are estimated to account for $66.5 \%$ of all years with disability in low- and middle-income countries (1). Disability increases with aging in both genders. Numerous studies show that ADL disability in old age is an important medico-social problem (5-10). If evaluated together with the economic development of the countries, it has been reported that disability decreased to $11.8 \%$ in countries with high incomes, and $18.0 \%$ in countries with low incomes (11). According to the information obtained from the Address Based Population Registration System, the population of Turkey was 83,154,997 as of December 31, 2019; 50.2\% of this population were men and $49.8 \%$ were women. The last study that estimates the distribution of disabled people across Turkey on a provincial basis is the '2011 Population and Housing Survey'.

According to the results of the Population and Housing Survey Study, 6.9\% (4,876,000 people) of those individuals aged 3 years or over have at least one disability; $5.9 \%$ for males and $7.9 \%$ for females. The European Union Labor Force Survey conducted a special study on the employment of disabled people in 2011. According to the results obtained from this report, the rate of individuals with a long-standing health condition or basic activity disorder is $33.2 \%$ in Turkey; the highest rate is seen in Finland (56\%) and the lowest is seen in Greece (14\%). The 'National Disability Data System' was created by the Ministry of Family and Social Policies and, according to these data, the number of disabled people alive is $2,533,209$, of which $1,423,334$ are men and $1,109,875$ are women. The number of people with severe disabilities is $777,569(12,13)$.

The aim of this study is to contribute to the statistics in this field by examining the health board records of our hospital, which has an important patient potential throughout Turkey, especially in Ankara and the surrounding cities.

\section{MATERIAL AND METHOD}

The study was planned as cross-sectional, retrospective, and descriptive study. Patients who applied to the Health Board of Health Sciences University Abdurrahman Yurtaslan Ankara Oncology Training and Research Hospital between 2015 and 2019 were included in this study. Ethical approval was received from Health Sciences University Abdurrahman Yurtaslan Ankara Oncology Training and Research Hospital Ethics Committee (Date: 08.07.2021, Decision No: 2021-06/1232). All procedures performed in this studywere in accordance with the ethical standards of the institutional and/or national research committee and with the 1964 Helsinki Declaration and its later amendments or comparable ethical standards. The International Statistical Classification of Diseases and Related Health Problems (ICD-10) list, as approved by the World Health Assembly, was used in the classification of diseases (14). Variables such as gender, age, disability rate, reporting period, and additional diseases were analyzed among the study population. Disability rate was calculated according to the Balthazard formula. Statistical Package for the Social Sciences (SPSS) version 21 (SPSS Inc., Chicago, IL, USA) was used for statistical analysis of the study data.

\section{RESULTS}

A total of 2,237 patients were included in our study, of which $41.9 \%(\mathrm{n}=938)$ were men and $58.1 \%$ (1299) were women; the number of female patients was higher than that of men. $(p<0.01)$. The mean age, regardless of gender, was $55.29 \pm 16.32$ years, $54.12 \pm 16.87$ years for men and $56.37 \pm 16.01$ years for women. The average rate of disability among the study population, calculated according to the Balthazard formula, was $66.4 \pm 21.29 \%$; $66.5 \pm 22.94 \%$ in men and $66.4 \pm 22.94 \%$ in women. There was no statistically significant difference was found between men and women regarding average rate of disability $(\mathrm{p}>0.05)$ (Table 1). While the average 
number of diseases in a person was found to be 2.12, this number was 2.02 for men and 2.18 for women. The average number of diseases in women was higher than it was in men $(\mathrm{p}<0.01)$ (Table 1). According to Balthazard formula, patients with a disability rate of $40 \%$ and above accounted for $90 \%(n=2013)$ of all the total number of patients, $41 \%(\mathrm{n}=827)$ and $59 \%(\mathrm{n}=1186)$ for the male and female patient groups, respectively. Overall, 5.1\% $(\mathrm{n}=115)$ of the patients were fully dependent, $5.4 \%$ $(n=120)$ were partially dependent, and $89.5 \%(n=2002)$ were not independent. Fully dependent, partially dependent, and independent patient rates among male patients were analyzed as being $5.4 \%(n=51), 6 \%$ $(\mathrm{n}=56)$, and $88.6 \%(\mathrm{n}=831)$, respectively; same rates in women were analyzed as being $4.9 \%(\mathrm{n}=64), 4.9 \%$ $(n=64)$, and $90.1 \%(n=1171)$, respectively (Table 1$)$. The rate of patients under 65 years of age $(n=1598,71.4 \%)$ was found to be higher than the rate of patients over 65 years of age $(n=636,28.4 \%)$. The rate of female patients aged under 65 and over 65 years was $71.3 \%$ and $28.7 \%$, respectively; the rate of male patients aged under 65 and over 65 years was $71.6 \%$ and $28.4 \%$, respectively (Table 1 ). The three most common diseases without gender discrimination were found to be; first, cancer ( $n=1339$, 28.19\%); second, endocrinological and metabolic diseases $(\mathrm{n}=578,12.16 \%)$; third, cardiovascular system diseases ( $n=1056,22.23 \%)$. Among for male patients., the three most common diseases were found to be: first, cancer ( $\mathrm{n}=472,24.10 \%$ ); second, endocrinological and metabolic diseases $(\mathrm{n}=212,10.82 \%)$; third, cardiovascular diseases $(n=393,20.07 \%)$. Concerning female patients; first, cancer $(\mathrm{n}=879,31.18 \%)$; second, endocrinological and metabolic diseases $(n=366$, $12.98 \%)$; and third, cardiovascular diseases $(n=663$, 23.52\%) (Table 1).

Among all patients who received reports, 71.9\% $(n=1610)$ received continuous reports (Table 2). When the patients were grouped according to their place of birth, Ankara ( $\mathrm{n}=755,29.7 \%)$ ranked first, Yozgat ranked second $(\mathrm{n}=151,5.9 \%)$, and Çorum ranked third $(n=132,5.2 \%)$.

\section{DISCUSSION}

Our study is important because it reflects the disabilityrelated records of a health institution in Turkey with reference hospital status. In our study, the rate of female patients was higher than males $(58.1 \%$ and $41.9 \%$, respectively) and the most common disease group was found to be cancer (28.2\%). The average disability rate among patients was $66.4 \pm 21.29 \%$, with men and women having similar rates $(66.4 \pm 22.94 \%$ and $66.5 \pm 22.94 \%$, respectively). Patients with a disability rate of $40 \%$ or above were found to comprise $90 \%$ of the total number of patients and $5.1 \%$ of fully dependent patients.

On evaluation of the gender distribution of the patient profiles who applied to the health board, the rate of male and female distribution was analyzed as follows: $60.9 \%$ of them were female and $39.1 \%$ were male in the study by Koçak et al. (15); 52.4\% were male and 39.1\% were female in the study by Çakır et al. (16); 59\% were male and $47.6 \%$ were female in the study by Benli et al. (17); $61.5 \%$ of them were male and $38.5 \%$ were female in the study by Baltac1 et al. (18); $45.4 \%$ were female and $54.6 \%$ were male in the study by Uysal et al. (19); $32 \%$ were female; $68 \%$ were male in the study by Adar et al. (20), and $17.8 \%$ were female and $82.2 \%$ male in the study by Özdil (21). In our study, the rate of female

\begin{tabular}{|ccc|}
\hline Table 2. Validity period of disability report & \\
\hline Validity period (month) & Number of patient (n) & $\%$ \\
\hline 12 & 231 & 10.3 \\
24 & 88 & 4 \\
36 & 44 & 2 \\
60 & 264 & 11.8 \\
Permanent (Continuous) & 1610 & 71.9 \\
\hline
\end{tabular}

\begin{tabular}{|c|c|c|c|c|}
\hline & Male & Female & Total & $\mathbf{p}$ \\
\hline Gender (n/\%) & $938 / 41.9$ & $1299 / 58,1$ & 2237 & $<0.01$ \\
\hline Age $($ mean $\pm S D)$ & $54.12 \pm 16.87$ & $56.37 \pm 16.01$ & $55.29 \pm 16.32$ & $>0.05$ \\
\hline Average disability rate & $66.5 \pm 22.94$ & $66.4 \pm 22.94$ & $66.4 \pm 21.29$ & $>0.05$ \\
\hline Cancer (n/\%) & $472 / 24.10$ & $879 / 31.18$ & $1339 / 28.19$ & \\
\hline Endocrinological and metabolic diseases (n/\%) & $212 / 10.82$ & $366 / 12.98$ & $578 / 12.16$ & \\
\hline Cardiovascular diseases (n/\%) & $393 / 20.07$ & $663 / 23.52$ & $1056 / 22.2$ & \\
\hline Average number of diseases in a person (n) & 2.02 & 2.18 & 2.12 & $<0.01$ \\
\hline According to average disability rate $\geq 40 \%$ ( $\mathrm{n} / \%)$ & $827 / 88.2$ & $1186 / 91.3$ & $2013 / 90$ & $<0.01$ \\
\hline Fully dependent (n/\%) & $51 / 5.4$ & $64 / 4.9$ & $115 / 5.1$ & \\
\hline Partially dependent (n/\%) & $56 / 6$ & $64 / 4.9$ & $120 / 5.4$ & \\
\hline Independent (n/\%) & $831 / 88.6$ & $1171 / 90.1$ & $2002 / 89.5$ & \\
\hline$<65$ years of age $(n / \%)$ & $672 / 71.6$ & $926 / 71.3$ & $1598 / 71.4$ & \\
\hline$>65$ years of age $(n / \%)$ & $266 / 28.4$ & $266 / 28.7$ & $636 / 28.4$ & \\
\hline
\end{tabular}


patients was $58.1 \%$, and the rate of male patients was $41.9 \%$. On evaluation of the literature, it can be seen that only the study by Koçak et al. included more female patients than male patients, as was the case for our study.

The average age of those patients who applied to the Health Board for a disability report was then evaluated. In our study, this average age was found to be $55.29 \pm 16.32$ years; $54.12 \pm 16.87$ years for males and $56.37 \pm 16.01$ years for females. In the study by Kocak et al. (15), which was conducted using a geriatric patient group, the mean age of patients was $77.62 \pm 7.74$ years; $78.07 \pm 7.54$ years for women and $76.93 \pm 8.02$ years for men. In the study by Cakır et al. (16), in which patients aged 18 years and under were not included, the mean age of patients was found to be $57.14 \pm 17.61$ years. In the study conducted at İnönü University (18), the mean age was $33.18 \pm 26.63$ years; $31.69 \pm 25.62$ years for men, and $35.50 \pm 28$ years for women. In a study conducted at Dicle University (20), the mean age of patients was found to be $36.97 \pm 25.76$ years. In the study conducted at Afyonkarahisar University (20) the mean age was $37.57 \pm 26.03$.

In our study, the average rate of disability, calculated according to the Balthazard formula, was $66.4 \pm 21.29 \%$; $66.5 \pm 22.94 \%$ among men and $66.4 \pm 22.94 \%$ among women. In a study conducted with geriatric patients in the Kirşehir region, this rate was found to be $79.96 \pm 17.79 \%$; $79.66 \pm 17.61 \%$ among women and $80.41 \pm 18.24 \%$ among men (15). It was calculated as $59.58 \pm 24.33 \%$ for the Karsiyaka State Hospital study (16), 67.36 $\pm 22.53 \%$ for the Inonu University study (18), $55.13 \pm 28.96 \%$ for the Dicle University study (19), 61.02 $\pm 27.45 \%$ Afyonkarahisar University study (20), and $55.85 \pm 26.00$ for the Gaziantep University (21).

According to the regulations, the "severely disabled" definition determines those people who will benefit from those rights related to disability at the highest level. These rights include many privileges, from transportation to care fees. In the study by Koçak et al. (15), the rate of severely disabled patients was found to be $28.9 \%$; furthermore, the rate of severely disabled people was found to be $15.7 \%$ in the study by Çakır et al. (16), 21.5\% in the study by Benli et al. (17), 56.3\% in the study by Baltac1 et al. (18), 36.4\% in the study Adar et al. (20) and 5.1\% for our study. It was found that the rate found in our study is quite different from those of other studies.

In our study, the rate of patients whose disability was not limited to a certain period but that was continuously evaluated was found to be $71.9 \%$. Among other studies in the literature, the rate of patients with continuous disability was reported as being $44.7 \%$ in the study of Koçak et al. (15), 91.3\% in the study by Çakır et al. (16),
$62 \%$ in the study by Benli et al. (17), 57.6\% in the study by Baltac1 et al. (18),48.4\% in the study by Uysal et al. (19), 38.7\% in the study Adar et al. (20), and 71.5\% in the study Özdil et al. (21).

According to the relevant law, disabled individuals are required to obtain a Disability Health Board Report of at least $40 \%$ in order to benefit from the rights and opportunities provided to them (2). The rate of patients with a disability above $40 \%$ was found to be $96 \%$ in the study by Koçak et al. (15) , 80.7\% in the study by Cakir et al. (16), 69.5\% in the study by Benli et al. (17), 91.1\% in the study by Baltaci et al. (18), 74.4\% in the study by Uysal et al. (19), and 38.7\% in the study Adar et al. (20); in our study, this rate was found to be $90 \%$.

Worldwide, the ranking of disability adjusted life years (DALYs) is as follows: first, neuropsychiatric diseases (13\%); second, injuries (12\%); third, cardiovascular disease $(10 \%)$; fourth, perinatal conditions (7\%); fifth, respiratory infections (6\%); sixth, HIV/AIDS (6\%); seventh, malignant neoplasms (5\%) (22). In our study, the most common three disease groups classified according to the ICD 10 encoding were oncological diseases, endocrine and metabolic disorders, and cardiovascular disorders, respectively. In the study by Koçak et al. (15), this ranking was found to be cardiovascular, musculoskeletal, and visual disorders, respectively. In the study by Cakir et al. (16), endocrinological problems ranked first, musculoskeletal diseases ranked second, and cardiovascular diseases ranked third. In the study by Benli et al. (17), musculoskeletal diseases were ranked first; ear, nose, and throat diseases were ranked second; and visual system diseases were ranked third. In the study by Uysal et al. (19), it was stated that most reports were prepared for mental disorders, followed by visual disorders in second place.

\section{CONCLUSION}

As a result, hospital health boards play an important role in the detection and grading of disabilities. When we compared the data we obtained in our study with the literature, certain differences were observed. It is thought that these differences may be related to hospital roles, or may be due to differences of interpretation among the health boards. For this reason, it is important to follow up whether the standards are applied as much as developing standards that will ensure unity in practice.

\section{ETHICAL DECLARATIONS}

Ethics Committee Approval: The study was initiated with the approval of the Ankara Dr. Abdurrahman Yurtaslan Oncology Training and Research Hospital Ethics Committee (Date: 08.07.2021, Decision No: 2021-06/1232). 
Informed Consent: Because the study was designed retrospectively, no written informed consent form was obtained from patients.

Referee Evaluation Process: Externally peer-reviewed.

Conflict of Interest Statement: The authors have no conflicts of interest to declare.

Financial Disclosure: The authors declared that this study has received no financial support.

Author Contributions: All of the authors declare that they have all participated in the design, execution, and analysis of the paper, and that they have approved the final version.

\section{REFERENCES}

1. WHO. World report of disability. Available online: https://www. who.int/disabilities/world_report/2011/report.pdf

2. Özürlülük Ölçütü, Sınıflandırması ve Özürlülere Verilecek Sağlık Kurulu Raporları Hakkında Yönetmelik.Resmi Gazete: Özürlüler İdaresi Başkanlığı; 30/03/2013. sayı: 28603.

3. WHO. Disability and health. Available online: https://www.who. int/news-room/fact-sheets/detail/disability-and-health

4. https://apps.who.int/iris/bitstream/handle/10665/42407/ 9241545429.pdf

5. Sonn U, Asberg KH. Assessment of activities of daily living in the elderly. A study of a population of 76-year-olds in Gothenburg, Sweden. Scand J Rehabil Med 1991; 23: 193-202.

6. Sonn U. Longitudinal studies of dependence in daily life activities among elderly persons. Scand J Rehabil Med Suppl. 1996; 34: 1-35.

7. Gill TM, Guo Z, Allore HG. The epidemiology of bathing disability in older persons. J Am Geriatr Soc 2006; 54: 1524-30.

8. Liu Z, Han L, Wang X, Feng Q, Gill TM. Disability prior to death among the oldest-old in China. J Gerontol A Biol Sci Med Sci 2018; 73: 1701-7.

9. Fong JH, Feng J. Patterns of functional disability in the oldest adults in China. J Am Geriatr Soc 2016; 64: 1890-4.

10. Fong JH. Disability incidence and functional decline among older adults with major chronic diseases. BMC Geriatr 2019; 19: 323.

11.Inan S, Peker G, Tekiner S, Ak F, Dagli Z. A glance at disability, the situation of disabled people and provision of health care in Turkey. TAF Prevent Med Bull 2013; 12: 723-8.

12. Nüfus ve Demografi. Türkiye İstatistik Kurumu. www. tuik.gov.tr

13.Engelli ve Yaşlı İstatistik Bülteni- Mayıs 2020. Engelli ve Yaşlı Hizmetleri Genel Müdürlüğü. T.C. Aile, Çalışma ve Sosyal Hizmetler Bakanlığı.

14.WHO. International Statistical Classification of Diseases and Related Health Problems (ICD). Available online: https://www. who.int/standards/classifications/classification-of-diseases

15. Aybala Koçak F, Kurt EE, Şaş S ve ark. Kırsal bölgede özürlü sağlık kuruluna başvuran geriatrik hastaların özürlülük dağılımı. Turk J Osteoporos 2018; 24: 92-9.

16. Çakır G, Şenol E, Işıl AM 2014 yılında Karşıyaka Devlet Hastanesi Engelli Sağlık Kurulunca düzenlenen raporların incelenmesi Tepecik Eğit ve Araşt Hast Derg 2017; 27: 197-202.

17.Benli AR, Demir Yazıcı Ş, Yazıcı O, Çörtük M, İnci H, Çetin Benli N. Sağlık kuruluna başvuru nedenlerinin değerlendirilmesi. Konuralp Tip Derg 2016; 8: 167-72.

18. Baltacı H, Kayhan Tetik B, Selçuk EB, Baltacı M. İnönü Üniversitesi Turgut Özal Tip Merkezi 2015 yılı Özürlü Sağlık Kuruluna başvuran olguların incelenmesi Türk Aile Hek Derg 2017; 21: 91-100.
19. Uysal C, Bulut M, Kaya C ve ark. Dicle Üniversitesi Hastaneleri Özürlü Kurulu'na başvuran olguların incelenmesi. Adli Tip Derg /J Forensic Med 2013; 27: 1.

20. Adar S, Yağan Ş, Ertan AB ve ark. Afyonkarahisar Sağlık Bilimleri Üniversitesi Hastanesi Sağlık Kurulu’nca düzenlenen raporların incelenmesi. Kocatepe Tip Derg 2021; 22: 326-332

21.Özdil S. Gaziantep Üniversitesi Tip Fakültesi Şahinbey Uygulama ve Araştırma Hastanesi tarafından Ocak 2004-Temmuz 2007 tarihleri arasında verilen özürlü sağlık kurulu raporlarının incelenmesi. Uzmanlık Tezi. Gaziantep: Gaziantep Üniversitesi Tip Fakültesi, Adli Tip Anabilim Dalı, 2008.

22.Department of Mental Health and Substance Dependence, Noncommunicable Diseases and Mental Health, World Health Organization, Geneva-2003. Investing in Mental Health. http:// www.who.int/mental_health/media/investing_mnh.pdf 